\title{
Impact Of Firm Specific Factors On Capital Structure Decision: An Empirical Study Of Albanian Firms.
}

\author{
Anila Çekrezi ${ }^{1}$,
}

\begin{abstract}
:
This paper attempts to explore the impact of firm specific factors on capital structure decision for a sample of 65 non- listed firms, which operate in Albania, over the period 2008-2011.In this paper are used three capital structure measures ; short -term debt to total assets (STDA), long- term debt to total assets (LTDA) and total debt to total assets (TDTA) as dependent variables and four dependent variables: tangibility(TANG), liquidity (LIQ), profitability(ROA=return on assets) and size (SIZE). The investigation uses panel data procedure and the data are taken from balance sheets and include only accounting measures on the firm's leverage. This study found that tangibility (the ratio of fixed assets to total assets), liquidity (the ratio of current assets to current liabilities) profitability (the ratio of earnings after taxes to total assets) and size (natural logarithm of total assets) have a significant impact on leverage. Also empirical evidence reveals a significant negative relation of ROA to leverage and a significant positive relation of SIZE to leverage. And the second objective of this study is to identify the impact of industry classification on firm's leverage, using a dummy variable for the trade sector. So one of the hypothesis tested is if financial leverage is independent of industry classification. Results reveal that long term debt to total assets and total debt to total assets ratios are significantly different across Albanian industries.
\end{abstract}

Keywords: Albania, Capital structure; Firm’s Specific Factors, Leverage.

\section{Introduction}

According to Brigham \& Ehrhardt (2008) capital structure refers to the firm mixture of debt and equity. Therefore, a value-maximizing firm will establish an optimal capital structure and then raise new capital to target this optimal capital structure over time (Brigham and Ehrhardt 2008). Modigliani and Miller (1958)

\footnotetext{
${ }^{1}$ Department of Finance and Accounting, University “A.Xhuvani” Elbasan, Albania
} 
have identified two criteria of rational decision-making, namely (1) the maximization of profits and (2) the maximization of market value. According to the first criterion, a physical asset is worth acquiring if it will increase the net profit of the owners of the firm. But net profit will increase only if the expected rate of return, or yield, of the asset exceeds the rate of interest. According to the second criterion, an asset is worth acquiring if it increases the value of the owners' equity, i.e., if it adds more to the market value of the firm than the costs of acquisition (Modigliani \& Miller, 1958, p. 262).

"In fact, the profit maximization criterion is no longer even well defined. Under uncertainty there corresponds to each decision of the firm not a unique profit outcome, but a plurality of mutually exclusive outcomes which can at best be described by a subjective probability distribution. The profit outcome, in short, has become a random variable and as such its maximization no longer has an operational meaning" (Modigliani and Miller, 1958, p. 263).

By including market imperfections, firms seem to get an optimal, valuemaximizing debt-equity ratio by trading off the advantages of debt against the disadvantages. So firms will set a target debt ratio and gradually will move towards achieving it (Myers, 1984).

In the theory of firm's capital structure and financing decisions, the pecking order theory was suggested by Myers \& Majluf (1984). The pecking order theory contradicts the existence of financial targets, and states that firms follow a financing hierarchy: internal funds are preferred above external financing (Myers, 1984; Myers and Majluf, 1984)

Different authors have studied the firm's specific factors which influence the company's financial decisions ( Titman \&Wessels ,1988; Rajan \& Zingales ,1995; Antoniou, Guney and Paudyal ,2002; Frank \& Goyal, 2009) and this study attempts to measure the effect of firm's specific determinants on the firm's choice among debt and equity for a sample of 65 non-traded Albanian firms using short-term debt (SDTA), long-term debt (LDTA) and total debt (TD) ratios as dependent variables. The firm's specific factors used in this empirical study are tangibility (TANG), liquidity (LIQ), profitability (ROA) and size (SIZE).

This study is focused on providing empirical evidence on the relationship between the choice of capital structure and firm's specific factors and on proving the existence of a relation between the firm's industry and leverage of non-traded small firms in Albania.

The data has been retrieved from the Annual Reports submitted by the firms to the State Tax Office. A sample of 65 firms over the period 2008-2011, is used in the analysis and in lack of an active stock market are been calculated only the book leverage-ratios of each firm. 
The rest of this paper is organized as follows: the next section is literature review on the issue discussed; the third and the fourth sections describes the data and the selection of measures. The fifth section describes the hypotheses and the econometric model. Results will be discussed in section six and section seven draws the conclusions.

\section{Literature review}

There are different studies done by researchers on capital structure theories beginning with the modern theory of Miller and Modigliani of 1958 and 1963 and continuing with the more recent ones.The basic theorem states that, under certain conditions the value of a firm is unaffected by how the firm is financed (Modigliani \& Miller, 1958). So according to Modigliani and Miller (1958), capital structure is irrelevant and internal and external finance can be perfect substitutes of each other. Modigliani and Miller made two conclusions under the perfect capital market conditions. Their first 'proposition' was that the value of a company is not affected by its capital structure. Their second 'proposition' stated that the cost of equity for a leveraged firm is equal to the cost of equity for an unleveraged firm, plus an added premium for financial risk. The trade-off theory is a development of the MM theorem but taking in consideration the effects of taxes and bankruptcy costs. This theory is considered as the first step for the development of many other theories which have studied how firms choose their capital structure. Modigliani and Miller's (1958) theory can be used to describe how firms use taxation to manipulate profitability and to choose an optimum debt level. Debt level at the other side increases the risk of bankruptcy or as we call it the bankruptcy costs because as the debt to equity ratio increases the debt holders will require higher interest rates but also the shareholders will pretend higher profits for their investments. (Brealey \& Myers, 2003, p. 508-509) According to Brealey \& Myers (2003) financial managers often think of the firm's debt-equity decision as a trade-off between interest tax shields and the costs of financial distress. By including market imperfections, firms seem to get an optimal, value-maximizing debtequity ratio by trading off the advantages of debt against the disadvantages. So firms will set a target debt ratio and gradually will move towards achieving it (Myers, 1984).

The pecking order theory contradicts the existence of financial targets, and states that firms follow a financing hierarchy: internal funds are preferred above external financing(Myers, 1984; Myers \& Majluf, 1984) When firms need additional funds they follow the below pecking order: First they use internally funds ( retained earnings), they adjust they target dividend payout in order to let unaffected the dividend flow (also if a firm has insufficient cash flow from 
internal sources, it draws down cash and marketable securities), and at last if external finance is required firm prefer (in order of preference):debt, hybrids securities(for example convertible bonds) and issue equity. (Myers, 1984; Myers \& Majluf, 1984).So, firms do not have a target debt ratio and the reason for this hierarchy is that internal funds are supposed to be the less costly source of finance not subject to any outside interference. This theory suggests a negative relationship between profitability and leverage. Pecking order theory (Myers, 1984; Myers \& Majliuf, 1984) describes a hierarchy of financing choice a firm makes due to information asymmetry.

1. Firms prefer internal finance.

2. They adapt their target dividend payout ratios to their investment opportunities, although dividends are sticky and target payout ratios are only gradually adjusted to shifts in the extent of valuable investment opportunities.

3. Sticky dividend policies, plus unpredictable fluctuations in profitability and investment opportunities, mean that internally-generated cash flow may be more or less than investment outlays. If it is less, the firm first draws down its cash balance or marketable securities.

4. If external finance is required, firms issue the safest security first. That is, they start with debt, then possibly hybrid securities such as convertible bonds, then perhaps equity as a last resort. In this story, there is no well-defined target debtequity mix, because there are two kinds of equity, internal and external, one at the top of the pecking order and one at the bottom. Each firm's observed debt ratio reflects its cumulative requirements for external finance (Myers, 1984).

\section{Data}

This study is based on the data collected on 65 non-traded firms in Albania over the period 2008-2011.The firms belong to different sectors including trade, construction, service, production, pharmacy and fuel. The average of the total assets of the firms in the sample is approximately 100.921.158 ALL (ALL is an acronym for Albanian Lek, Albanian's currency or 720.865 Euro (we note that the exchange rate is roughly 140 ALL/Euro). So all the firms can be classified as SME and based on Strategic Plan for the Development of SME-s 2007-2013(Ministry of Energy, Transport and Economy of Albania, 2007), more than 99 percent of the Albanian businesses can be classified as small and medium enterprises. Most part of the firms in the sample belong to the commercial sector (23 firms from 65 in total) and to the service sector (11 firms from 65 in total), followed by the construction and production sectors. All the data are collected from the Balance Sheet Annual Reports, the official document send to the State Office of Taxes. 
Table 1: Sample selection

\begin{tabular}{|l|l|l|l|}
\hline Sector & Number of firms & No of years covered & No of observations \\
\hline Trade & 23 & 4 & 92 \\
\hline Non-trade sector & 42 & 4 & 168 \\
\hline Total & 65 & 4 & 260 \\
\hline
\end{tabular}

\section{Selection Measures}

Previous studies have used the different forms of leverage ratio to represent the capital structure of a firm. Frank and Goyal (2009) have noticed that, most studies focused on a single measure of leverage using total debt like total debt to total assets or total debt to equity. So Pandey ( 2002) takes in consideration only the ratio of Total debt-to-total asset (TD/A) at book value to identify the firm's leverage but other studies as that of Huang and Song (2004) employed six measures of leverage and the Total liabilities ratio (TL) is used as the main measure of leverage.

Some authors suggested the use of market value of debt as a proper measurement for capital structure as it reflects in a better way the current position and future position of the firms (Frank \& Goyal, 2005 and Welch, 2004).

Among the reason way this study use the book value of leverage instead of market value are: the inexistence of capital markets in Albania and because many studies used the accounting measures (book value) to decide on financial stability (Kumar, 2005).So Kumar (2005) study on more than 2000 Indian firms, has calculated the a company's financial leverage by dividing long-term debt by shareholders equity without including the market-based variables. This study has used following three measures as a proxy of capital structure choice. Here leverage is defined as:

$$
\begin{aligned}
\text { SDTA } & =\frac{\text { Short term } \text { debt }}{\text { Total } \text { asset }} \\
\text { LDTA } & =\frac{\text { Long term debt }}{\text { Total asset }} \\
\text { TDTA } & =\frac{\text { Total debt }}{\text { Total asset }}
\end{aligned}
$$




\section{Tangibility}

Tangibility is defined as the ratio of fixed assets to total assets and different studies have proven that the type of assets owned by a firm influence firm's capital decision (Myers ,1977; Drobetz \&Fix ,2003; Daskalakis \& Psillaki ,2006 ; Pandey ,2002). Following Titman and Wessels (1988), Rajan \&Zingales (1995), Pandey (2002) Drobetz \&Fix (2003) the ratio of fixed assets over total asset as a measure of tangibility will be used in order to prove the existence or not of a positive relation between fixed assets and firm's capital structure decision.

Tangibility $=\frac{\text { Fixed assets }}{\text { Total asset }}$

\section{Profitability}

Different researches have used different measures of profitability .Daskalakis and Psillaki (2006 ) measured profitability as the ratio of earnings before taxes (EBT) divided by total assets. Rajan and Zingales (1995) used EBITDA divided by book value of assets to measure profitability. Antoniou et al (2002) define profitability as a ratio of operating income (earnings before interest, taxes, and depreciation) to total assets. Following Degryse, Goeij and Kappert (2009) this study will measure profitability with ROA:

$\mathrm{ROA}=\frac{\text { Earning after taxes }}{\text { Total asset }}$

\section{Liquidity}

Among the studies which used the ratio of current asset over current liabilities to denote liquidity are studies done by Antoniou et al. (2002), Andersen (2002), Sogorb and Lopez(2003), and Shahjahanpour, Ghalambor and Aflatooni (2010). In line with the literature, liquidity is also defined as the ratio of current assets over current liabilities in this study.

Liquidity $=\frac{\text { Current assets }}{\text { Current liabilities }}$

\section{Size}

Following Sogorb and Lopez (2003), Zeitun and Tian (2007) and Frank and Goyal (2009) size will be measured as the natural logarithm of total assets with the aim of controlling a possible non-linearity in the data, and the consequent problem of heteroskedasticity (Sogorb and Lopez ,2003).

$$
\text { Size }=\text { Natural logarithm }(\text { Total assets })
$$




\section{Hypotheses and the econometric model}

In order to identify the effect the selected determinants on the firm's capital structure decision and the effect of industry the study used five hypotheses which are presented below:

Hypothesis 1: Asset tangibility is positively related to capital structure decision. According to trade off theory tangible assets, such as property, plant, and equipment are easier for outsiders to value than intangibles such as the value of goodwill from an acquisition - this lowers expected distress costs. In addition, tangibility makes it difficult for shareholders to substitute high-risk assets for low-risk ones. The lower expected costs of distress and fewer debt-related agency problems predict a positive relation between tangibility and leverage (Frank \& Goyal, 2009, p.19). The pecking order theory makes opposite predictions. Low information asymmetry associated with tangible assets makes equity issuances less costly. Thus, leverage ratios should be lower for firms with higher tangibility (Frank \& Goyal, 2009, p.19).

\section{Hypothesis 2: Liquidity is negatively related to capital structure decision.}

The relationship between cash holdings (liquidity) and leverage is not clearly determined under the trade-off model (Saddour, 2006, p.8).According to pecking order theory liquidity has a negative relation with leverage. If amount of money needed for investment are higher than retained earnings, firms should issue new debt. "Thus, leverage increases whereas cash holdings fall. However, when investment needs are less than retained earnings, firms repay their debt and accumulate cash" (Saddour, 2006, p.9).

\section{Hypothesis 3: Profitability is negatively related to capital structure decision.}

Trade off-theory suggest that profitable firms face lower expected costs of financial distress and find interest tax shields more valuable. Thus, the tax and the bankruptcy costs perspective predicts that profitable firms use more debt( Frank and Goyal ,2009,p. 15).Regarding book leverage, the trade off theory predicts that it should be positively correlated with expected profitability because higher expected profitability corresponds to higher benefits of debt and lower costs of financial distress. Such a relation will be observed empirically if the costs of adjusting leverage are relatively low and adjustments occur relatively quickly. For market leverage, the tradeoff theory does not have a definite prediction since firm value also increases with expected profitability $(\mathrm{Xu}, 2012$, p.2).

Hypothesis 4: The size of the company is positively related to the level of debt. Large, more diversified, firms face lower default risk. Thus, the trade-off theory predicts larger, more mature firms to have relatively more debt (Frank and Goyal, 2009, p.16) "Large firms have a reputation in debt markets and consequently face lower agency costs of debt. Hence, the trade-off theory predicts that leverage and firm size should be positively related" (Frank \& Goyal 2005, p.38). The pecking order theory is 
usually interpreted as predicting an inverse relation between leverage and firm size (Frank \& Goyal, 2005, p.38). Large firms have had an opportunity to retain earnings (Frank \& Goyal, 2009, p.16).This means that they should decrease firm's debt.

\section{Hypothesis 5: There is difference in capital structure choice among industries.}

Different researchers conclude that the industry in which operate the firm, effect capital structure decision (Jensen \& Mecklig 1976; DeAngelo \& Masulis ,1980; Jensen ,1986; Harris \& Raviv 1991; Hovakimian, Opler, \& Titman,2001; Drobetz \& Fix ,2003; Frank \& Goyal ,2009). DeAngelo \& Masulis (1980) proved that with the presence of corporate tax shield substitutes for debt (e.g. depreciation, depletion, amortization, and investment tax credits), each firm will have "a unique interior optimum leverage decision with or without leverage related costs" (DeAngelo \& Masulis ,1980, p.3).

Table 2: The predicted signs according to trade-off theory and pecking order theory of the explanatory variables.

\begin{tabular}{|l|l|l|l|c|c|}
\hline Variable & $\begin{array}{l}\text { Variable } \\
\text { Name }\end{array}$ & Definition & $\begin{array}{l}\text { Trade-off } \\
\text { theory }\end{array}$ & $\begin{array}{c}\text { Pecking } \\
\text { order theory }\end{array}$ & $\begin{array}{l}\text { Expected } \\
\text { sight from } \\
\text { the study }\end{array}$ \\
\hline Tangibility & TANG & $\begin{array}{l}\text { Fixed assets/ } \\
\text { Total assets }\end{array}$ & Positive & Negative & Positive \\
\hline Liquidity & LIQ & $\begin{array}{l}\text { Current assets/ } \\
\text { Total assets }\end{array}$ & Positive & Negative & Positive \\
\hline Profitability & ROA & $\begin{array}{l}\text { EAT/ } \\
\text { Total assets }\end{array}$ & Positive & Negative & Negative \\
\hline Size & SIZE & Log(Total assets) & Positive & Negative & Negative \\
\hline
\end{tabular}

In this study is used multiple regression analysis to test SDTA, LDTA and TDTA as dependent variable with the fourth independent variables. The econometric functional models used to determine the firm-specific factors influencing leverage, are specifically given in the equation 1,2 , and 3 :

$Y s d t a=\alpha 0+\alpha 1 * T A N G+\alpha 2 * L I Q+\alpha 3 * R O A+\alpha 4 * S I Z E+\varepsilon \quad 1$

Yldta $=\beta 0+\beta 1 * T A N G+\beta 2 * L I Q+\beta 3 * R O A+\beta 4 * S I Z E+\lambda \quad 2$

$Y t d t a=\gamma 0+\gamma 1 * T A N G+\gamma 2 * L I Q+\gamma 3 * R O A+\gamma 4 * \operatorname{SIZE}+\eta$

The independent variables used in the analysis are:

TANG $=$ Fixed assets $/$ Total assets

LIQ = Current assets/Current liabilities

$\mathrm{ROA}=$ Earnings after taxes(EAT)/Total assets

SIZE $=$ Natural logarithm of total assets 
And the dependent variables are:

SDTA $=$ Short-term debt to total assets.

LDTA $=$ Long- term debt to total assets.

TDTA $=$ Total debt to total assets.

In order to test hypothesis five a dummy variable is used:

Dummy $=$ dummy variable for the trade sector . The dummy variable takes the value one if the firm belong to the trade sector and zero otherwise.

Using data as described earlier we will estimate all coefficients of equation one, two and equation three.

Table 3: Correlation coefficients, using the observations 1:1 - 65:4

$5 \%$ critical value (two-tailed) $=0.1217$ for $\mathrm{n}=260$

\begin{tabular}{|l|l|l|l|l|l|}
\hline SDTA & TANG & LIQ & ROA & SIZE & \\
\hline 1.0000 & -0.1456 & -0.3117 & -0.1321 & 0.1107 & SDTA \\
\hline & 1.0000 & 0.1272 & -0.1415 & 0.0280 & TANG \\
\hline & & 1.0000 & -0.0739 & -0.0674 & LIQ \\
\hline & & & 1.0000 & -0.1284 & ROA \\
\hline & & & & 1.0000 & SIZE \\
\hline
\end{tabular}

Table 4: Correlation coefficients, using the observations 1:1 - 65:4

$5 \%$ critical value (two-tailed) $=0.1217$ for $\mathrm{n}=260$

\begin{tabular}{|l|l|l|l|l|l|}
\hline LDTA & TANG & LIQ & ROA & SIZE & \\
\hline 1.0000 & 0.3236 & 0.2900 & -0.2273 & 0.1203 & LDTA \\
\hline & 1.0000 & 0.1272 & -0.1415 & 0.0280 & TANG \\
\hline & & 1.0000 & -0.0739 & -0.0674 & LIQ \\
\hline & & & 1.0000 & -0.1284 & ROA \\
\hline & & & & 1.0000 & SIZE \\
\hline
\end{tabular}

Table 5: Correlation coefficients, using the observations 1:1 - 65:4

$5 \%$ critical value (two-tailed) $=0.1217$ for $\mathrm{n}=260$

\begin{tabular}{|l|l|l|l|l|l|}
\hline TDTA & TANG & LIQ & ROA & SIZE & \\
\hline 1.0000 & 0.1876 & -0.0280 & -0.3852 & 0.2480 & TDTA \\
\hline & 1.0000 & 0.1272 & -0.1415 & 0.0280 & TANG \\
\hline & & 1.0000 & -0.0739 & -0.0674 & LIQ \\
\hline & & & 1.0000 & -0.1284 & ROA \\
\hline & & & & 1.0000 & SIZE \\
\hline
\end{tabular}

Table 3 shows the correlation between the explanatory variables specifically with respect to SDTA, Table 4 shows the correlation between the explanatory variables with respect to LDTA while Table 5 shows the correlation between the explanatory variables with respect to TDTA. As we can notice SDTA is negatively correlated with TANG 
(14.56 percent), LIQ (31.17 percent)and ROA (14.15 percent) but has a weak positive correlation with SIZE (11.07 percent).LDTA is positively correlated with TANG (32.36 percent), LIQ (29 percent) and SIZE (12.03 percent) but has a negative correlation with ROA (22.73 percent).Also it is demonstrated that TDTA is negatively correlated with LIQ(2.8 percent) and ROA (38.52 percent), but has a positive correlation with TANG(18.76 percent) and SIZE (24.8 percent).

Table 6: Summary Statistics, using the observations 1:1 - 16:4

\begin{tabular}{|l|l|l|l|l|l|l|l|l|}
\hline Variable & Mean & Median & Min. & Max. & St.Dev. & C.V. & Skew. & Kurt. \\
\hline SDTA & 0.3916 & 0.3852 & 0.0006 & 0.9941 & 0.2813 & 0.7183 & 0.2274 & -1.1099 \\
\hline LDTA & 0.1938 & 0.0208 & 0.0000 & 0.9702 & 0.2773 & 1.4310 & 1.2615 & 0.1708 \\
\hline TDTA & 0.5854 & 0.6334 & 0.0014 & 0.9941 & 0.2601 & 0.4443 & -0.6054 & -0.6889 \\
\hline TANG & 0.2640 & 0.1691 & 0.0000 & 0.9979 & 0.2753 & 1.0427 & 1.0799 & 0.0235 \\
\hline LIQ & 17.4616 & 1.7554 & 0.0597 & 583.188 & 70.0988 & 4.0145 & 6.4810 & 44.3742 \\
\hline ROA & 0.0881 & 0.0582 & -0.2247 & 0.8427 & 0.1280 & 1.4517 & 3.0557 & 12.8596 \\
\hline SIZE & 17.5355 & 17.4446 & 14.5250 & 20.9756 & 1.3210 & 0.0753 & 0.2763 & -0.4746 \\
\hline
\end{tabular}

Note: SDTA $=$ short term debt to total assets; LDTA = long term debt to total assets; TDTA $=$ total debt to total assets; $\mathrm{TANG}=$ fixed assets to total assets; $\mathrm{LIQ}=$ current assets to current liabilities. $\mathrm{ROA}=$ the return on assets; $\mathrm{SIZE}=$ the natural logarithm of total assets.

Table 6 reports summary statistics for the variables used in the study. It shows that the average short term debt to total assets (SDTA) for the sample as a whole is 0.3916 and the average long term debt to total assets (LDTA) is 0.1938 .

Employing panel data (cross pooled sectional data) analysis (Gujarati, 2004) and using Gretl (2012) statistical package we obtain the following output of regressions:

Table 7: Summary of models

\begin{tabular}{|l|l|l|l|}
\hline Variables & Model 1(WLS) & Model 2(WLS) & Model 3(WLS) \\
\hline Independent & Ysdta & Yldta & Ytdta \\
\hline TANG & $-0.2183^{* * *}$ & $0.3260^{* * *}$ & $0.1083^{* * *}$ \\
\hline LIQ & $-0.0011^{* * *}$ & $0.0012^{* * *}$ & -0.0002 \\
\hline ROA & $-0.3622^{* * *}$ & $-0.2737 * * *$ & $-0.7700^{* * *}$ \\
\hline SIZE & $0.0316^{* * *}$ & $0.0220^{* * *}$ & $0.0399^{* * *}$ \\
\hline Adjusted $\mathrm{R}^{2}$ & 0.24 & 0.39 & 0.32 \\
\hline
\end{tabular}

The models are as follows:

$$
\begin{array}{lr}
\text { Ysdta }=-0.07-0.218 * \text { TANG }-0.001 * L I Q-0.362 * R O A+0.0316 * S I Z E+\varepsilon & 1 \\
Y l d t a=-0.31+0.326 * T A N G+0.001 * L I Q-0.274 * R O A+0.022 * S I Z E+\lambda & 2
\end{array}
$$


$Y t d t a=-0.06+0.108 * T A N G-0.0002 * L I Q-0.770 * R O A+0.040 * S I Z E+\eta$

Table 8: Summary of models

\begin{tabular}{|l|l|l|l|}
\hline Variables & Model 1(WLS) & Model 2(WLS) & Model 3(WLS) \\
\hline Independent & Ysdta & Yldta & Ytdta \\
\hline TANG & $-0.2140^{* * *}$ & $0.3673^{* * *}$ & $0.1809^{* * *}$ \\
\hline LIQ & $-0.0012^{* * *}$ & $0.0010^{* * *}$ & $-0.0004^{* *}$ \\
\hline ROA & $-0.3537^{* * *}$ & $-0.2681^{* * *}$ & $-0.6760^{* * *}$ \\
\hline SIZE & $0.0286^{* * *}$ & $0.0168^{* *}$ & $0.0332^{* * *}$ \\
\hline Dummy & 0.0152 & $0.0712^{* * *}$ & $0.1357^{* * *}$ \\
\hline Adjusted $\mathrm{R}^{2}$ & 0.22 & 0.42 & 0.36 \\
\hline
\end{tabular}

Table 8 shows the respective coefficients if we include a dummy variable for the trade sector and the estimated regressions equations obtained are given below:

$$
\begin{aligned}
\text { Ysdta }=-0.02 & -0.214 * \text { TANG }-0.001 * \text { LIQ }-0.354 * \text { ROA }+0.029 * \text { SIZE } \\
& +0.0251 * \text { Dummy }+\varepsilon \\
\text { Yldta }=-0.25+ & 0.367 * \text { TANG }+0.001 * \text { LIQ }-0.268 * \text { ROA }+0.017 * \text { SIZE } \\
+ & 0.07 * \text { Dummy }+\lambda \\
\text { Ytdta }=-0.02+ & 0.181 * \text { TANG }-0.0004 * \text { LIQ }-0.676 * \text { ROA }+0.0332 * \text { SIZE } \\
+ & 0.136 * \text { Dummy }+\eta
\end{aligned}
$$

\section{Results}

It is proved a significant negative relation between SDTA and TANG and a significant positive relation between both LDTA and TDTA with TANG. This means that firms doesn't finance fixed assets with short term debt but with long term debt. This finding is not consistent with Daskalakis and Psillaki (2006) which found a negative relation between tangibility and total debt ratio.

And as predicted LIQ have a significant negative relation with SDTA and a significant positive relation with LDTA. However, there is no empirical evidence of a relation between LIQ and TDTA with the model's explanatory power being at levels of 0.32. Shahjahanpour et al. (2010) found that the correlation coefficient of liquidity and short term debts is negative and significant and equal to- 0.35 (of less than 5\% significant rate), and between liquidity and long term debt also negative and significant, which is not consistent with this study findings. Also we notice that the average liquidity of the sample is 17.46, 
resulting very high compared with that of Shahjahanpour et al. (2010) study which is equal to 1.25 .

Empirical evidence reveals a significant negative relation between the dependent variables and ROA. Among the studies which evidenced a negative relation between profitability and leverage are those of Titman and Wessels (1988), Rajan and Zingales (1995), Antoniou et al. (2002),Daskalakis and Psillaki (2006) ,Degryse et al. (2009), Frank and Goyal (2009) This finding is also in line with the pecking order theory stating that more profitable firms use retained earnings as their first choice of financing. This finding is not in line with Antoniou et al. (2002), Frank and Goyal (2003) and Xu (2012) studies that have proved a positive relation between profitability and leverage.

Also there is evidence of a positive relationship between the dependent variables and SIZE in all models. These results are in line with the findings of Titman and Wessels (1988), Rajan and Zingales (1995), Frank and Goyal (2009) which concluded that size has a significant positive relation with leverage. Daskalakis and Psillaki ( 2006)measured size as natural logarithm of sales revenue and capital structure as the ratio of total liabilities( long-term and shortterm liabilities) divided by the total assets of the firm and found a positive association between the two variables in both Greece and France sample.

Hypothesis five insists that leverage ratio should differ for industry variations. One dummy variable representing the trade sector is been used to examine the hypothesis that non -trade sector differ significantly from the trade one. It is found from the results that these two sectors are significantly different from each other in capital structure decisions. The dummy variable which is assigned equal to one for the trade sector and equal to zero for the non trade sector results positive and statistically significant into the second and third model. In this two models leverage is respectively measured using long term debt over total assets and total debt over total assets. So, the results show that industry is a significant factor in capital structure determination. Thus we cannot reject Hypothesis five. Sayeed (2011) also found industry to be significant determinant of capital structure.

\section{Conclusions}

This paper examines the role that the specific firm's factors including tangibility, profitability, size and liquidity have on capital structure choice for non-traded firms in Albania. The results indicate that there is empirical evidence to show that:

\section{Tangibility is negatively related to short term debt and positively related to long term debt and total debt ratio.}


2. Profitability measured with return on assets (ROA) is negatively related to short term debt, long term debt and total debt ratio. This finding is in line with pecking order theory which explains that firms prefer internal finance over external funds. If investments and dividends are fixed, then more profitable firms will become less levered over time (Frank and Goyal, 2009, p. 15).

3. Firm's size is positively related to short term debt, long term debt and total debt ratio and this finding is in line with trade off theory which predicts a positive relation between the two variables. According to this theory large firms face lower agency costs of debt.

4. Liquidity is negatively related to short term debt and positively related to long term debt.

5. Industry results to be a significant determinant of capital structure measured with LDTA and TDTA.

\section{References}

Anderson, R.W. (2002).Capital structure, firm liquidity and growth.NBB working paper ,no.27.

Antoniou,A.,Guney ,Y. \& Paudyal,K. (2002). Determinants of corporate capital structure: Evidence from European countries. University of Durham, working paper.

Brealey, R. \&Myers, S. (2003). Principles of Corporate Finance. New York, USA, McGraw Hill Companies.

Brigham, E. \& Ehrhardt,M.(2008) Financial Management: Theory and Practice. 12th ed., USA,Thomson Learning.

Daskalakis, N. \& Psillaki M.(2006). The determinants of capital structure of the SME's: Evidence from the Greek and the French firms, unpublished.

DeAngelo, H. \& Masulis, R.W.( 1980) .Optimal Capital Structure under Corporate and Personal Taxation. Journal of Financial Economics, 8, 3-29.

Degryse,H. , Goeij P. \& Kappert P.(2009). The impact of firm and industry characteristics on small firms' capital structure: Evidence from Dutch panel data. European Banking Center Discussion, paper no. 2009-03.

Drobetz, W. \&Fix, R. (2003).What are the determinants of the capital structure? Some evidence for Switzerland. working paper no.4/03, WWZ/ Department of Finance.

Frank, M.Z \& Goyal, V.K.(2009). Capital structure decisions: Which factors are reliably important? ,Financial Management, 38, 1-37.

Frank, M.Z. \& Goyal V.K. (2003).Testing the Pecking Order Theory of Capital Structure. Journal of Financial Economics, 67, 217-248. 
Frank, M.Z. \& Goyal, V.K (2005). Trade-off and pecking order theories of debt. B.Espen Eckbo,Handbook of Corporate Finance, Empirical Corporate Finance.

Gujarati,D.(2004). Basic Econometrics. 4th ed.USA, McGraw Hill.

Harris ,M. \& Raviv, A.(1991). The theory of capital structure, Journal of Finance, 46, 297-356. Hovakimian, A., Opler, T. \& Titman, S. (2001). The debt-equity choice. Journal of Financial and Quantitative Analysis, 36, 1-24.

Jensen, M. \&Meckling,W.(1976). Theory of the firm: Managerial behavior, agency costs, and ownership structure.Journal of Financial Economics, 3, 305-360.

Jensen, M.C. (1986).Agency cost of free cash flow, corporate finance, and takeovers. American Economic Review, 76, (2). Available at http://dx.doi.org/10.2139/ssrn.99580.

Kumar, J. (2005). Capital structure and Corporate Governance. Xavier Institute of Management, India, unpublished paper.

Modigliani, F. \& Miller,M.(1958). The cost of capital, corporate finance and the theory of investment. American Economic Review, 48, 261-297.

Myers, S. \&Majluf, N. (1984). Corporate financing and investment decisions when firms have information that investors do not have. Journal of Financial Economics, 13, 187-221.

Myers, S. (1977). Determinants of corporate borrowing.Journal of Financial Economics, 5, 147-175.

Myers, S. (1984). The capital structure puzzle. Journal of Finance, 39, 575-92.

Pandey ,I.(2002).Capital structure and market power interaction: Evidence from Malaysia. Indian Institute of Management, working paper, 2002.

Rajan, R. \& Zingales ,L.(1995). What do we know about capital structure? Some evidence from international data. Journal of Finance, 50(5), 1421-1460.

Republic of Albania, Ministry of Energy, Transport and Economy(2007).Programi strategjik per zhvillimin e SME-ve per periudhen 2007-2009.

Saddour, K. (2006). The determinants and the value of cash holdings: Evidence from French firms. CEREG, 1-33. Available: http://www.dauphine.fr/cereg/cahiers rech/cereg200606.pdf

Sayeed, M. A. (2011). The Determinants of Capital Structure for Selected Bangladeshi Listed Companies. International Review of Business Research Papers, 7( 2), 21-36.

Shahjahanpour, A. , Ghalambor, H. \& Aflatooni A.(2010).The determinants of capital structure choice in the Iranian companies.International Research Journal of Finance and Economics, 56,167-178.

Sogorb, F. \& López,J. (2003).Pecking order versus trade-off: An empirical approach to the small and medium enterprise capital structure. Instituto Valenciano De Investigaciones Económicas, S.A., working paper,2003.

Titman ,S. \& Wessels , R. (1988) .The determinants of capital structure choice. Journal of Finance, 43( 1),1-19.

Welch, I. (2004). Capital structure and stock returns. The Journal of Political Economy, Chicago. 112(1), 106-132.

Xu, J.(2012). Profitability and Capital Structure: Evidence from Import Penetration. Journal of Financial Economies, 106,427-446.

Zeitun, R. \& Tian,G. (2007). Capital structure and corporate performance: Evidence from Jordan. The Australasian Accounting Business \& Finance Journal,1, 40-61 